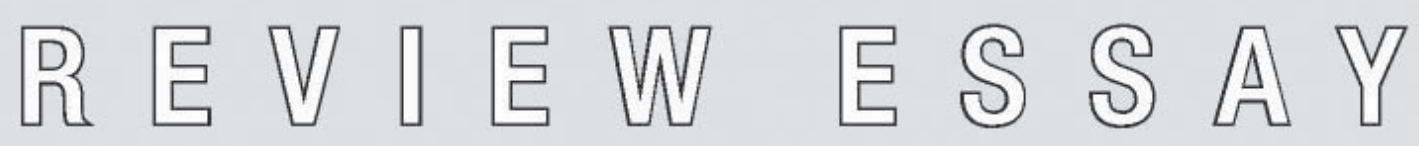
af Yvonne Mørck

\title{
Komplekse rejser og store udfordringer: Erfaringer fra East End
}

Michael Young og Peter Willmotts bog Family and Kinship in East London fra 1957 er en sociologisk klassiker. Den handler om Bethnal Green, der var et klassisk arbejderklassekvarter i Londons East End, som blev brudt op, da mange familier via efterkrigstidens boligpolitik mere eller mindre frivilligt flyttede til store nybyggede "housing estates" i Londons forstæder. Hvordan denne politik påvirkede arbejderklassefamilien, dens interne relationer og livet i lokalmiljøet er bogens hovedtemaer. Undersøgelsen, der bygger på empirisk data produceret fra 1953-55, er opdelt i to dele, hvoraf den første handler om East End-området og den anden del om et af de "housing estates", som nogle af familierne flyttede til. Begge forskere arbejdede enten i East End eller i det nye boligkvarter samtidig med, at en af dem boede det meste af tiden i East End med sin familie. Uformelle samtaler med beboere indgik således også som en del af undersøgelsesmaterialet. Omkring 1.000 beboere (ud af 54.000) blev interviewet $i$ en survey, og ud af disse blev et mindre antal unge ægtepar med børn interviewet flere gange.

Det er ikke så ofte, at forskere får mulighed for at "genbesøge" et område. Det er imidlertid overgået Young, for han har nemlig sammen med antropologerne Geoff Dench og Kate Gavron foretaget en opfølgende undersøgelse 40 år senere, dvs. i 1992/93 i, hvad de betegner som "det nye East End". Der blev igen iværksat en survey, der involverede 799 mennesker, der boede i East End (plus data om deres udvidede familier, dvs. fra 2.566 mennesker der boede i hhv. husholdene og udenfor). Der blev også fortaget kvalitative interviews med 51 beboere med hhv. "hvide" ${ }^{1}$ eller etniske britere og beboere med rød- 
der i Bangladesh (mange blev interviewet flere gange). For begge gruppers vedkommende involverede det både nytilflyttede og nogle, hvis familier havde boet i området i flere generationer. Også lokale skolelærere, socialarbejdere m.fl. blev interviewet, ligesom unge kvinder med rødder i Bangladesh blev interviewet over en længere periode.

Der er mange interessante temaer og teoretiske perspektiver i de to bøger, og der trækkes en række spændende tematiske tråde mellem de to undersøgelser. Her vil jeg imidlertid rette fokus mod familier og børn fra området, som satser på social mobilitet via uddannelse. Dette tema er nemlig stadigt aktuelt både i Storbritannien og i Danmark. For på trods af udbygningen af velfærdsstaten i begge lande vedbliver det for både etniske majoritetsbørn og etniske minoritetsbørn at være et vanskeligt projekt at bryde den negative sociale arv i relation til uddannelse, dvs. at blive "klasserejsende" (Mørck 2006, 2008). De to undersøgelser giver imidlertid et lærerigt indblik i nogle af processer, der er på spil under en sådan rejse. Klassekomponenten ser da også ud til atter en gang at få en mere fremtrædende plads på den akademiske dagsorden f.eks. i forbindelse med en intersektionalitetstilgang, hvor sammenvævning af klasse, køn og etnicitet står stærkt. Men hvis klasse ikke blot skal have en "progressiv" signalværdi, men reelt spille en rolle i f.eks. analyser af barrierer for uddannelse, kræver det mere viden om både strukturelle forhold og om, hvordan klasserejsende oplever deres komplekse rejser, herunder både interog intra-etniske forhold. Derfor er det værd at se nærmere på de to studier.

Young og Willmott har interviewet nogle af de meget få piger fra området, som havde gået i "grammar school" fra 1945-50, dvs. særlige skoler for børn, der blev bedømt bogligt begavede. Beretninger fra 24 af disse piger, som var voksne på interviewtidspunktet, dvs. midt i 1950'erne, giver et retrospektivt indblik i, hvilke reaktioner de mødte i familien og blandt voksne og børn i lokalmiljøet, da de forsatte med at gå i skole, mens stort set alle andre børn forlod den som 14-årige og i, hvordan de havde følt sig (u)tilpas i de nye skoleomgivelser. Forfatterne beskriver, hvordan pigerne blev isolerede i relation til deres oprindelige miljø. Det var langt fra økonomisk omkostningsfrist for forældrene at lade døtrene fortsætte med skolegangen. Det var f.eks. kutyme, at en del af de penge, som døtrene ville have tjent ved at tage erhvervsarbejde, skulle have gået til mødrene. Selvom det primært var mødrene, der betalte prisen for døtrenes uddannelse, var det især dem, der støttede døtrene i at gå videre. Det var oftest de yngste børn, der havde mulighed for uddannelse, for så kunne de ældre søskende være med til at betale for de yngre. Det var forventninger om en fremtidig større økonomisk tryghed, der var drivkraften bag valget om mere uddannelse.

Der var imidlertid tilsyneladende ikke megen støtte at hente hos hverken voksne eller børn i lokalområdet, da disse udviste fjendtlighed over for pigerne. De voksne så skævt til unge, herunder pigerne, som gjorde noget andet end majoriteten, nemlig at forlade skolen i en ung alder og tage et ufaglært 
arbejde. Pigernes forhold til de andre børn blev også berørt af deres skolevalg. De mistede deres venner, som havde været deres tidligere klassekammerater. Når pigerne kom hjem fra skole, skulle de lave lektier og kunne derfor ikke deltage i hverken gadens aktiviteter eller i husarbejde. Pigerne gik også i særlige skoleuniformer, der signalerede, at de var "anderledes" end de andre børn; uniformen blev af de andre børn set som et tegn på deres egen mindreværdighed, så de kom med negative bemærkninger over for pigerne. Når de andre unge kvinder i kvarteret forlod skolen, tjente de penge, så de kunne klæde sig smart, mens det ikke var tilfældet for pigerne, der forsatte i skolen. En anden form for klassepres, som de blev udsat for, kom fra andre elever i den videregående skole, som var bedre økonomisk og socio-kulturelt stillede, f.eks. havde de andre piger råd til fine kjoler til skolefester. Og selvom Bethnal Green-pigerne efterhånden blev tosprogede i den forstand, at de talte "cockney", dvs. arbejderklasse-londonsk i hjemmemiljøet og standardengelsk i skolen, følte de sig alligevel utilpasse og mindreværdige i forhold til elever fra bedrestillede miljøer. Hvis de i hjemmemiljøet talte, som det blev forventet i skolen, blev de imidlertid anset for snobbede.

Hvordan så pigernes liv ud 20 år efter deres skolegang? 6 af kvinderne var ugifte eller fraskilte, og de enten boede eller arbejdede sammen med deres mødre. De havde haft svært ved at finde mænd, som de havde noget til fælles med. For disse kvinder havde mere uddannelse ikke ført dem længere væk fra forældrene - snarere tværtimod. 9 kvinder havde giftet sig "opad", dvs. med mænd der havde mere uddannelse end deres fædre. Skønt disse kvinder boede uden for East End i bedrestillede områder, havde de regelmæssig kontakt med deres forældre. Nogle af dem følte sig imidlertid fremmedgjorte $\mathrm{i}$ forhold til oprindelsesfamilien, f.eks. i relation til hvad de interesserede sig for og hvad angår sprog. Forældrene talte "cockney", mens de selv talte standardengelsk, og de ønskede, at deres børn talte "pænt" engelsk. Nogle af kvinderne havde skyldfølelser, fordi de modsat deres forældre og søskende havde haft uddannelsesmuligheder. Samtidig havde de ofre, som især mødrene havde ydet for at give datteren adgang til uddannelse, skabt stærke bånd mellem dem. Skønt kvinderne gav udtryk for, at der kunne være spændinger i familien pga. kvindernes sociale mobilitet, var de meget loyale over for deres oprindelsesfamilie. På dette område lignede de kvinder, som var blevet boende i Bethnal Green. Endelig var 9 kvinder gift med mænd, som repræsenterede hhv. samme socialgruppe eller en lavere end kvindernes fædre. Kvindernes uddannelse syntes ikke at have medvirket til placere dem i end anderledes position end kvinder, der ikke havde fået mere uddannelse.

Hvordan så social mobilitet via uddannelse ud i East End i slutningen af det 20.århundrede? Der er sket store forandringer i befolkningssammensætningen i de forgangne 40 år. I midten af 1950'erne var der få ikke-hvide beboere i East End, og i 1953-undersøgelsen deltog ingen med etnisk minoritetsbaggrund. I 1992/93-surveyen derimod udgjorde mennesker med rødder 
i Bangladesh $40 \%$ af husholdsbeboerne, mens hvide udgjorde $48 \%$. Dench, Gavron \& Young argumenterer for, at der er sket forandringer i politik og den moralske økonomi snarere end i de materielle omstændigheder i East End. Årsagen til denne transformation findes ifølge forfatterne i de moderne medborgerskabsformer, som blev skabt af efterkrigstidens velfærdsstat. Tidligere udspillede konflikter mellem beboerne i East End og nytilkomne sig i relation til konkurrence på det økonomiske felt, dvs. arbejde. Det er stadig tilfældet, men denne konkurrence bliver i stadig højere grad erstattet af konkurrence om adgang til velfærdsstøtte og offentlig service. Især skolesystemet udgør et af de væsentligste konfliktfelter mellem den etniske majoritetsbefolkning og de etniske minoriteter.

Det dominerende syn på skolegang og uddannelse i East End har traditionelt været, at den viden, man kunne opnå via skolegang, ikke spillede nogen større rolle. Hvad børnene lærte ud over at læse og skrive blev ikke anset for noget, man kunne bruge til noget. For drengenes vedkommende skulle de tjene deres penge ved manuelt arbejde, dvs. at fysisk styrke og sejhed var afgørende (se også Willis 1977). Det betød mere for drengenes fremtidige arbejdsmuligheder, at de f.eks. havde et svømmecertifikat for så kunne de søge arbejde ved havnen eller på Themsen. Denne ligegyldighed over for uddannelse blandt etniske majoritetsfamilier er i nyere tid blevet forstærket dels af, at der er flere skilsmisser og familiesammenbrud i disse familier og dels af, at der er kommet et øget antal etniske minoritetselever i skolerne, især børn med rødder i Bangladesh. Disse minoritetsbørn tildeles særlig opmærksomhed og ressourcer de første skoleår pga. deres manglende engelskkundskaber. Dette skaber både en stemning af konkurrence i klasseværelset mellem etniske majoritetsbørn og etniske minoritetsbørn og kan føre til direkte fjendtlighed over for skolen fra de hvide forældres side. Denne harme bliver styrket af, at større børn med rødder i Bangladesh klarer sig fagligt bedre end hvide børn. Hvorfor klarer mange bengalske børn sig godt fagligt? Børn med rødder i Bangladesh har en ganske anden opfattelse af skolesystemet end etniske majoritetselever. For indvandrere, der kommer fra en helt anden livsform (landsbyliv og et samfund hvor uddannelse er noget, man selv skal betale for) og med en særskilt kulturel arv, udgør skolesystemet en velkommen hurtig vej til forståelse af og forberedelse til livet i Storbritannien. Selvom forældre kan have visse forbehold over for dele af det britiske samfund, vil de gerne have, at de unge tager en uddannelse, og at de bliver boende i Storbritannien.

På trods af en række barrierer såsom sparsomme engelskkundskaber ved skolestart, at mange af børnene tages ud af skolen i længere perioder for at være i Bangladesh, og at familierne bor i overbefolkede boliger klarer mange af børnene sig godt fagligt - ikke mindst pigerne. Forældres støtte er en vigtig faktor for denne succes, dvs. dét at de værdsætter uddannelse styrker børnenes sociale mobilitet. Børnene er bedre disciplinerede og medgørlige end hvide børn, hvilket afspejles i deres faglige resultater. Især pigerne klarer sig 
godt, men også etnisk britiske piger klarer sig bedre end etnisk britiske drenge i de lokale skoler. Nogle majoritetsforældre mener, at årsagen til, at mange etniske minoritetsbørn klarer sig fagligt godt, er, at lærerne bruger mere tid på disse børn end på hvide børn - tid der går fra hvide børn. Blandt etniske majoritetsforældre kan spores en betydelig ambivalens: På den ene side er der lokal tradition for ikke at tillægge uddannelse særlig meget betydning og at modsætte sig skolens indblanding i familielivet. På den anden side hvis lærerne kan støtte lokale børn i skolegangen, så er det irriterende, at dette "gode" går til nyankomne. Der spores en tendens til, at de etniske majoritetsforældre, der er mest ambitiøse på deres børns vegne, flytter deres børn fra skoler med mange etniske minoritetsbørn til mere "hvide skoler", der formodes at være med lydhøre over for etniske majoritetsbørn.

Hvordan kan man imødegå en sådan udvikling og sådanne reaktioner fra dele af den hvide arbejderklasse i East End? Disse processer, som er en del af, hvad der er blevet kaldt "post-kolonial melankoli", dvs. dét at majoritetsmedlemmer fra arbejderklassen og den lavere middelklasse opfatter sig selv som taberne i de nye sociale hierarkier f.eks. i uddannelsessystemet (Gilroy 2004 i Garner 2007) viser, at det er afgørende, at der dannes alliancer mellem mennesker, der indtager samme klasseplacering - uanset etnisk og racial baggrund. Klasseplacering er stadig en kilde til fælles erfaringer og problemer, dvs. den kunne, som den amerikanske forsker Martha E. Gïnemez foreslår, danne grundlag for kollektive mobiliseringer og organiseringer i en række kontekster som f.eks. lokalsamfund og skoler. På det teoretiske felt kan man, som Gïmenez også gør, argumentere for nødvendigheden af at bringe "lidt mere klasse" ind i samfundsvidenskabelig forskning om ulighed. Migrationsstrømme forårsaget af den globale kapitalisme skaber stadig større heterogenitet $\mathrm{i}$ befolkningerne i de vestlige lande. Derfor er det vigtigere end tidligere dels at bygge bro mellem den falske kløft mellem klasse- og identitetspolitik og dels at udvikle teorier og politiske analyser, der kan sammentænke klasse, etnicitet og "race" på nye måder (Gïmenez 2006).

Danmark står over for tilsvarende problemstillinger. Også her er der pres på og transformation af velfærdsstaten bl.a. pga. indvandring og globalisering, ligesom der er store udfordringer inden for skole- og uddannelsessystemet i relation til social mobilitet. For at imødekomme disse udfordringer er erfaringer fra både det gamle og det nye East End værd at tage til efterretning.

Yvonne Mørck

E-mail: ym@ruc.dk

\section{Noter}

1. Forfatterne anvender betegnelsen hvide. Jeg bruger hvide, etniske britere og etnisk majoritet synonymt. 


\section{Litteratur}

Dench, Geoff; Gavron, Kate \& Young, Michael 2006: The New East End. Kinship, Race and Conflict. London: Profile Books.

Gïmenez, Martha E. 2006: "With a Little class: A Critique of Identity Politics", Ethnicities, vol. 6 (3).

Garner, Steve 2007: Whiteness. An Introduction. London: Routledge.

Mørck, Yvonne 2006: “Why not intersectionality? A concept at work in modern complex societies. Intersectionality and class travels". Paper No. 61. FREIA: Feminist Research Center in Aalborg, Institute for History, International and Social Studies.

Mørck, Yvonne 2008: "Komplekse rejser. Ungdomsforskning", Center for Ungdomsforskning, nr. 1 \& 2.

Willis, Paul 1977: Learning to Labour: How Working Class Kids get Working Class Jobs. Farnbrough, Hants: Saxon House.

Young, Michael \& Willmott, Peter 1990 [1957]: Family and Kinship in East London. London/Middlesex: Penguin Books. 